Jurnal Perikanan (2020) Volume 10. No. $2: 158-166$

DOI : https://doi.org/10.29303/jp.v10i2.206

\title{
PENGARUH PERBEDAAN JARAK TANAM TERHADAP PERTUMBUHAN RUMPUT LAUT (Eucheuma cottonii) HASIL KULTUR JARINGAN DENGAN METODE PATOK DASAR DI PERAIRAN GERUPUK
}

\section{THE EFFECT OF DIFFERENT PLANT SPACING ON SEAWEED (Eucheuma cottonii) GROWTH TISSUE ISOLATION RESULTS WITH OFF BOTTOM METHOD IN GERUPUK WATERS}

\author{
Muhammad Supiandi ${ }^{1 *}$, Nunik Cokrowati ${ }^{1 *}$, Ibadur Rahman ${ }^{1)}$ \\ ${ }^{1)}$ Program Studi Budidaya Perairan, Universitas Mataram \\ *)alamat korespondensi : md.supiandi@gmail.com
}

\begin{abstract}
Abstrak
Penelitian ini bertujuan untuk mengetahui pengaruh perbedaan jarak tanam terhadap pertumbuhan rumput laut (Eucheuma cottonii) hasil kultur jaringan dengan metode patok dasar.Penelitian ini dilakukan perlakuan dengan perbedaan jarak tanam rumput laut hasil kultur jaringan. Beberapa refrensi budidaya rumput laut menganjurkan jarak tanam yang diterapkan adalah $25 \mathrm{~cm}$. Namun, jarak tersebut diduga terlalu lebar karena ukuran bibit rumput laut Eucheuma cottonii hasil kultur jaringan lebih kecil (50 g) dari ukuran benih konvensional (100 g). Penelitian ini menggunakan Rancangan Acak Lengkap (RAL). Terdapat 4 peralakuan, yaitu P0 dengan jarak $25 \mathrm{~cm}$ sebagai perlakuan kontrol, P1 dengan jarak $20 \mathrm{~cm}$, P2 dengan jarak $15 \mathrm{~cm}$ dan P3 dengan jarak $10 \mathrm{~cm}$, dengan masing-masing 4 ulangan.Data hasil penelitian dianalisis menggunakan analisis sidik ragam atau analysis of variance (ANOVA) pada taraf nyata $5 \%$ dengan selang kepercayaan $95 \%$. Hasil penelitian pertumbuhan mutlak paling tinggi didapatkan pada perlakuan P1 dengan nilai rata-rata $124 \mathrm{~g}$, laju pertumbuhan spesifik paling tinggi terdapat pada perlakuan P1 dengan nilai rata-rata 4,15 $\%$ /hari, dan nilai rendemen karaginan menunjukkan hasil tidak berbeda nyata.Pengamatan rendemen karaginan pada Eucheuma cottonii menunjukkan hasil berurutan pada masingmasing perlakuan yaitu kontrol sebesar 17\%, P1 dan P2 sebesar 16\%, dan P3 sebesar 14\%. Kesimpulan dari penelitian ini adalah jarak tanam memiiki pengaruh yang nyata terhadap pertumbuhan rumput laut Eucheuma cottonii kultur jaringan dengan metode patok dasar (off bottom). Dengan jarak tanam terbaik dalam penelitian ini adalah P1 $(20 \mathrm{~cm})$
\end{abstract}

Kata kunci: Jarak tanam, rumput laut, pertumbuhan dan karaginan.

\begin{abstract}
This study aims to determine the effect of different plant spacing on the growth of seaweed (Eucheuma cottonii) tissue culture results using the bottom off method. This research uses a completely randomized design (CRD). This research was carried out treatment with different plant spacing tissue culture results. Some references on seaweed cultivation advocated applied planting distance is $25 \mathrm{~cm}$. However, distance it is thought to be too wide due to the size of the Eucheuma cottonii tissue culture yields are smaller $(50 \mathrm{~g})$ than conventional seed sizes $(100 \mathrm{~g})$. There are 4 treatments, namely P0 with a distance of 25 $\mathrm{cm}$ as a control treatment, P1 with a distance of $20 \mathrm{~cm}, \mathrm{P} 2$ with a distance of $15 \mathrm{~cm}$ and P3
\end{abstract}


with a distance of $10 \mathrm{~cm}$, each with 4 replications with a seedling initial weight of $50 \mathrm{~g}$. Research data were analyzed using analysis of variance or analysis of variance (ANOVA) at $5 \%$ significance level with a $95 \%$ confidence interval. The highest absolute growth was in the P1 treatment with an average value of $124 \mathrm{~g}$, the highest specific growth rate was in the P1 treatment with an average value of $4.15 \% /$ day, and the carrageenan yield showed no significant difference. Observation of carrageenan yields on Eucheuma cottonii showed sequential results in each treatment namely control by $17 \%, \mathrm{P} 1$ and $\mathrm{P} 2$ by $16 \%$, and $\mathrm{P} 3$ by $14 \%$. The conclusion of this research is distance planting has a real influence on the growth of seaweed Eucheuma cottonii tissue culture by off bottom method. The best planting distance in thid study is $\mathrm{P} 1(20 \mathrm{~cm})$.

Keywords: Seaweed, plant spacing, growth and carrageenan.

\section{PENDAHULUAN}

Rumput laut (seaweed) dewasa ini merupakan salah satu komoditas hasil laut yang penting. Disamping mempunyai banyak kegunaan, rumput laut juga sebagai sumber penghasilan bagi masyarakat pesisir dan devisa negara. Rumput laut memiliki posisi penting dalam produksi perikanan Indonesia, khususnya usaha perikanan non ikan (Asikin et al., 2011).Indonesiamemiliki luas area untuk kegiatan budidaya rumput laut sebesar 1.110.900ha, tetapi pengembangan budidayarumput laut baru memanfaatkan lahanseluas 222.180 ha $(20 \%$ dari luas arealpotensial) (Wijayanto et al., 2011).

Eucheuma cottoniiadalah salah satunya rumput laut yang banyak dibudidayakan oleh masyarakat. Jenis ini banyak dibudidayakan karena teknologi produksinya relatif murah dan mudah serta penanganan pasca panen relatif mudah dan sederhana. Selain sebagai bahan baku industri, rumput laut jenis ini juga dapat diolah menjadi makanan yang dapat dikonsumsi langsung (Wijayanto et al., 2011).

Budidaya rumput laut Eucheuma cottonii biasanya dilakukan dengan metode rakit apung, long-line, serta patok dasar. Penelitian ini dilakukan dengan metode patok dasar. Menurut BSN (2011), metode patok dasar (off bottom) merupakan cara menumbuhkan rumput laut di atas dasar perairan (masih terendam air $20-50 \mathrm{~cm}$ pada saat surut terendah) dengan menggunakan tali yang diikatkan pada patok yang dipasang secara teratur. Patok yang digunakan dapat berupa kayu, bambu atau besi yang berfungsi sebagai pancang untuk mengikatkan tali ris utama.

Permasalahan dalam budidaya rumput laut salah satunya adalah penggunaan bibit rumput laut yang kualitasnya kurang baik. Bibit rumput laut yang digunakan berasal dari budidaya sebelumnya yang telah digunakan untuk budidaya selama berulang kali, sehingga pertumbuhannya lambat dan mudah terserang penyakit. Hal tersebut mengakibatkan produksi rumput laut kurang maksimal. Salah satu upaya untuk meningkatkan produksi rumput laut adalah menggunakan bibit yang berkualitas yaitu bibit hasil kultur jaringan (Rukni, 2016).

Penelitian ini dilakukan perlakuan dengan perbedaan jarak tanam rumput laut hasil kultur jaringan. Beberapa refrensi budidaya rumput laut menganjurkan jarak tanam yang diterapkan adalah $25 \mathrm{~cm}$ (Desy et al., 2016). Namun, jarak tersebut diduga terlalu lebar karena ukuran bibit rumput laut Eucheuma cottonii hasil kultur jaringan lebih kecil (50 g) dari ukuran benih konvensional (100 g). Jarak yang digunakan dalam penelitian ini adalah 25 $\mathrm{cm}$ (kontrol), $20 \mathrm{~cm}, 15 \mathrm{~cm}$ dan $10 \mathrm{~cm}$. Menurut Pong-Masak dan Sarira (2018), jarak tanam yang terlalu jauh mengakibatkan pemborosan dalam penggunaan tempat atau kurang efisien 
Jurnal Perikanan (2020) Volume 10. No. 2 : 158-166

DOI : https://doi.org/10.29303/jp.v10i2.206

karena banyak lahan yang tidak dimanfaatkan.

Tujuan penelitian ini adalah untuk mengetahui pengaruh jarak tanam terhadap pertumbuhan bibit rumput laut Eucheuma cottonii hasil kultur jaringan dengan metode patok dasar. Manfaat yang diperoleh dari penelitian adalah didapatkannya informasi mengenai pengaruh jarak tanam terhadap pertumbuhan bibit rumput laut Eucheuma cottonii hasil kultur jaringan pada metode budidaya patok dasar.

\section{METODE PENELITIAN}

Penelitian ini dilaksanakan pada tanggal 10 Maret sampai dengan 10 April 2020, bertempat di Pantai Siwak, Gerupuk, Kecamatan Pujut, Kabupaten Lombok Tengah. Dilanjutkan pada tanggal 13-15 April 2020, untuk dilakukan pengekstrakan karaginan di Desa Marga Mulya, Kecamatan Bungku Barat, Kabupaten Morowali, Provinsi Sulawesi Tengah.

Adapun perlakuan yang dilakukan adalah sebagai berikut (Gambar 1)

- Jarak tanam $25 \mathrm{~cm}$ (kontrol) P0

- Jarak tanam $20 \mathrm{~cm} \quad \mathrm{P1}$

- Jarak tanam $15 \mathrm{~cm} \mathrm{P2}$

- Jarak tanam $10 \mathrm{~cm} \mathrm{P3}$

$20 \mathrm{~cm} 15 \mathrm{~cm} 25 \mathrm{~cm} 10 \mathrm{~cm} 20 \mathrm{~cm} 25 \mathrm{~cm} 15 \mathrm{~cm} 20 \mathrm{~cm} 25 \mathrm{~cm} 15 \mathrm{~cm}$

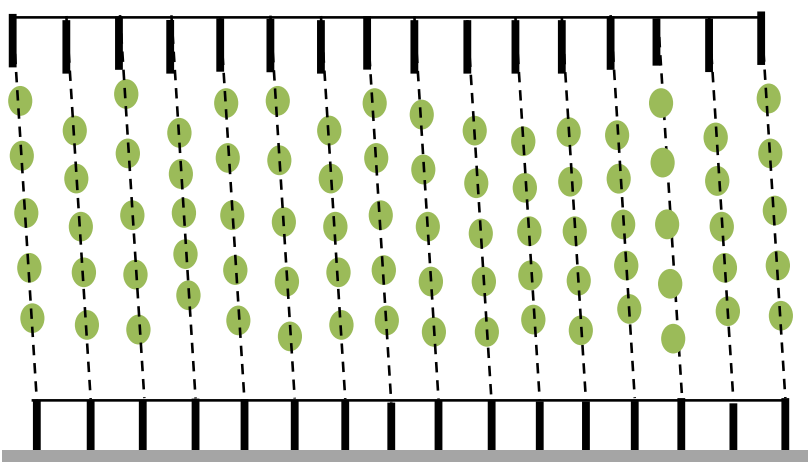

$\begin{array}{llllllll}\mathrm{P}_{1} \mathrm{U}_{2} \mathrm{P}_{2} \mathrm{U}_{4} & \mathrm{P}_{0} \mathrm{U}_{3} & \mathrm{P}_{3} \mathrm{U}_{2} & \mathrm{P}_{1} \mathrm{U}_{3} & \mathrm{P}_{0} \mathrm{U}_{2} & \mathrm{P}_{2} \mathrm{U}_{1} & \mathrm{P}_{1} \mathrm{U}_{1} & \mathrm{P}_{0} \mathrm{U}_{4}\end{array}$

Gambar 1. Tata letak tali ris per-unit percobaan

\section{Parameter Penelitian}

Paremeter utama dalam penelitian ini adalah pertumbuhan mutlak, laju

pertumbuhan spesifik dan karagenan.Perhitungan pertumbuhan mutlak dilakukan untuk mengetahui selisih total rumput laut yang telah ditanam.

$G=W t-W o$.......(Effendy, 2003 dalam Cokrowati et al., 2018)

Perhitungan laju pertumbuhan harian bertujuan untuk mengetahui laju pertumbuhan rumput laut pada setiap harinya.

$L P S=\frac{\text { LnWt-LnWo }}{t} \times 100 \% \ldots . . . \quad$ (Dawes, 1994 dalam Cokrowati et al., 2018)

Rendemen karaginan adalah hasil ekstraksi rumput laut Eucheuma cottonii dengan cara sebagai berikut; rumput laut kering ditimbang sebanyak $100 \mathrm{~g}$, dicuci bersih dengan air tawar, direndam dengan air tawar 12 jam, rumput laut direndam kembali dengan $\mathrm{NaOH} 1 \%$, kemudian dibilas dengan air tawar bersih, rumput laut diblender sampai halus, rumput laut halus diekstrak dengan api kecil dan ditambahkan air $3 \mathrm{~L}$, rebus hingga homogen selama 2 jam, disaring dalam kondisi masih panas, hasil saringan langsung dibilas dengan ethanol 90\% hingga rata, dikering anginkan selama 12 jam, selanjutnya oven dengan suhu rendah $60-80^{\circ} \mathrm{C}$ hingga berbentuk lembaran karaginan, lembar karaginan diblender kemudidan ditimbang dan dihitung berdasarkan rasio antara bobot karaginan dengan bobot rumput laut kering yang digunakan pada masing-masing perlakuan. $R=\frac{B K}{B R L} x 100 \%$....(FMC Corp, 1977 dalam Failu et al., 2016)

Keterangan: $\mathrm{G}=$ pertumbuhan mutlak $(\mathrm{g})$, LPS = laju pertumbuhan spesifik (\%), W= bobot rumput laut $(\mathrm{g}), \mathrm{t}=$ lama pemeliharaan (hari), $\mathrm{R}=$ rendemen $(\%)$, $\mathrm{BK}=$ bobot karaginan $(\mathrm{g})$, dan $\mathrm{BRL}=$ bobot rumput laut $(\mathrm{g})$.

Parameter kualitas air yang diamati dalam penelitian ini adalah suhu, $\mathrm{DO}, \mathrm{pH}$, kedalaman, kecepatan arus, salinitas, nitrat, fosfat. 


\section{Analisis Data}

Data hasil penelitian dianalisis menggunakan analisis sidik ragam atau analysis of variance (ANOVA) pada taraf nyata $5 \%$ dengan selang kepercayaan $95 \%$. Jika dari data sidik ragam diketahui bahwa perlakuan menunjukan pengaruh yang berbeda nyata (signifikan), maka untuk melihat perlakuan yang memberikan hasil beda nyata dilakukan uji lanjut Duncan's Multiple Range Test (DMRT) taraf 5\%.

\section{HASIL}

Pertumbuhan Mutlak

Pertumbuhan mutlak rumput laut yang diamati dari berat awal penanaman hingga minggu akhir penimbangan dalam penelitian dapat dilihat pada gambar 2 berikut:

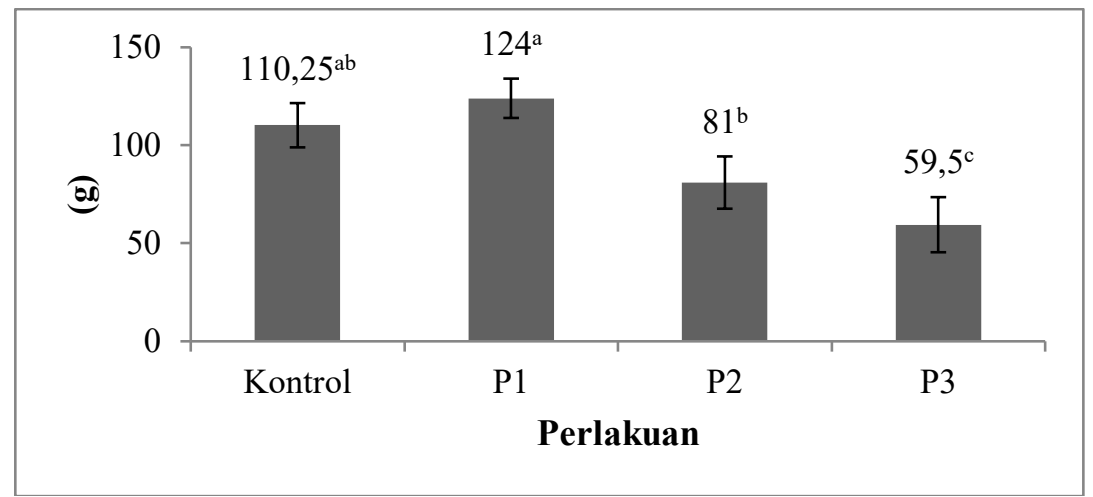

Gambar 2. Grafik pertumbuhan mutlak rumput laut

Keterangan: Kontrol $=$ jarak tanam $25 \mathrm{~cm}, \mathrm{P} 1=$ jarak tanam $20 \mathrm{~cm}, \mathrm{P} 2=$ jarak tanam $15 \mathrm{~cm}$, $\mathrm{P} 3=$ jarak tanam $10 \mathrm{~cm}$.

Pertumbuhan mutlak paling tinggi terdapat pada perlakuan P1 dengan nilai rata-rata $124 \mathrm{~g}$, kemudian disusul dengan perlakuan P0 (kontrol) dengan nilai ratarata $110,25 \mathrm{~g}$, selanjutnya $\mathrm{P} 2$ dengan nilai rata-rata $81 \mathrm{~g}$, dan data yang paling rendah didapatkan pada perlakuan P3 jarak tanam $10 \mathrm{~cm}$ dengan nilai rata-rata 59,5 g dalam sebulan masa pemeliharaan.

\section{Laju Pertumbuhan Spesifik}

Laju pertumbuhan spesifik rumput laut yang diamati dari berat awal penanaman hingga minggu akhir penimbangan dalam penelitian dapat dilihat pada gambar berikut:

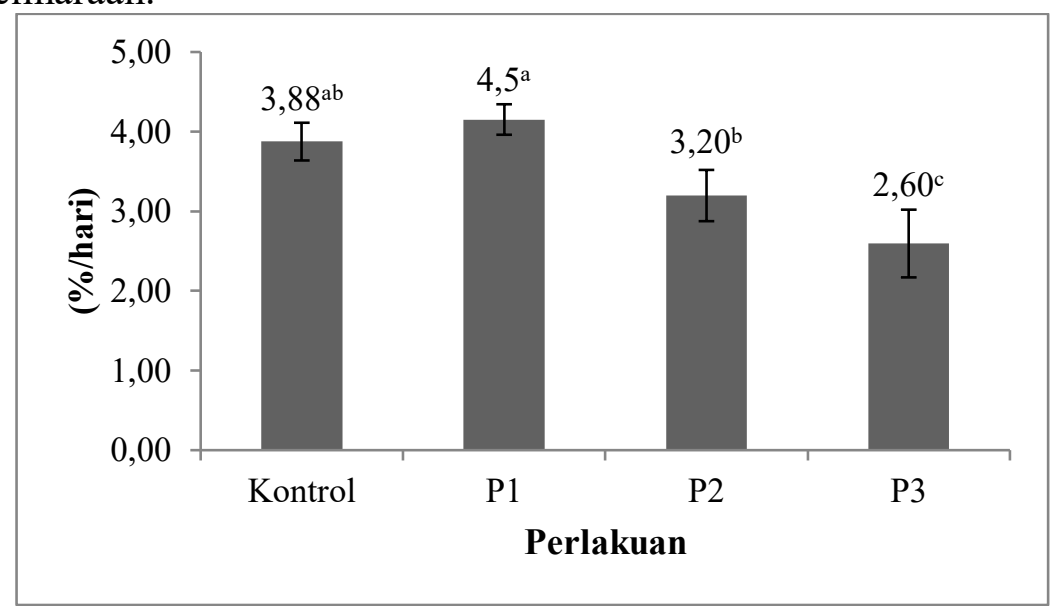

Gambar 3. Grafik laju pertumbuhan spesifik rumput laut

Keterangan: Kontrol $=$ jarak tanam $25 \mathrm{~cm}, \mathrm{P} 1=$ jarak tanam $20 \mathrm{~cm}, \mathrm{P} 2=$ jarak tanam $15 \mathrm{~cm}$, $\mathrm{P} 3=$ jarak tanam $10 \mathrm{~cm}$. 
Laju pertumbuhan spesifik paling tinggi terdapat pada perlakuan P1 dengan nilai rata-rata $4,15 \% /$ hari, kemudian diikuti dengan perlakuan P0 (kontrol) dengan nilai rata-rata $3,88 \% /$ hari, selanjutnya $\mathrm{P} 2$ dengan nilai rata-rata 3,20 $\% /$ hari, dan data yang paling rendah didapatkan pada perlakuan $\mathrm{P} 3$ dengan nilai rata-rata 2,60\%/hari dalam sebulan masa pemeliharaan.

\section{Rendemen Karaginan}

Kadar kandungan karaginan rumput laut Eucheuma cottoni yang didapatkan dari penelitian ini dapat dilihat pada gambar berikut:

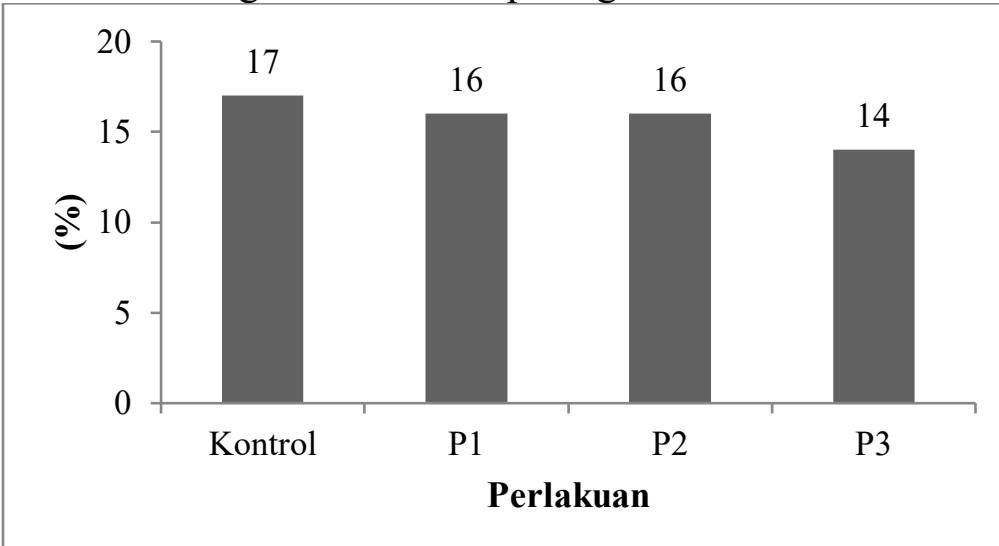

Gambar 4. Grafik rendemen karaginan

Keterangan: Kontrol $=$ jarak tanam $25 \mathrm{~cm}, \mathrm{P} 1=$ jarak tanam $20 \mathrm{~cm}, \mathrm{P} 2=$ jarak tanam $15 \mathrm{~cm}$, $\mathrm{P} 3=$ jarak tanam $10 \mathrm{~cm}$.

Nilai rendemen karaginan menunjukkan hasil tidak berbeda nyata. Pengamatan rendemen karaginan pada Eucheuma cottonii menunjukkan hasil berurutan pada masing-masing perlakuan yaitu kontrol sebesar $17 \%$, P1 dan P2 sebesar 16\%, dan P3 sebesar 14\%.

\section{Kualitas Air}

Kualitas air yang didapatkan selama penelitian yang diukur setiap 7 hari satu kali data tersaji di

Tabel 1 sebagai berikut:

\begin{tabular}{|c|c|c|}
\hline Parameter & Nilai & Referensi \\
\hline Suhu $\left({ }^{\circ} \mathrm{C}\right)$ & $27-30$ & $\begin{array}{l}\text { 26-30 (Pong-Masak dan } \\
\text { Sarira, 2015) }\end{array}$ \\
\hline $\mathrm{DO}(\mathrm{ppm})$ & $\begin{array}{l}4,64- \\
5,7\end{array}$ & $\begin{array}{l}\text { 4,4-5,4 (Nur et al., } \\
2016)\end{array}$ \\
\hline $\mathrm{pH}$ & $7,9-9$ & $\begin{array}{l}\text { 7,5-8,4 (Pong-Masak } \\
\text { dan Sarira, 2018) }\end{array}$ \\
\hline $\begin{array}{l}\text { Salinitas } \\
\text { (ppt) }\end{array}$ & $31-34$ & $\begin{array}{l}\text { 28-35 (Pongarrang et } \\
\text { al., 2013) }\end{array}$ \\
\hline Kecepatan & $20-$ & 20-40 (Togatorop et al., \\
\hline
\end{tabular}

\begin{tabular}{|c|c|c|}
\hline Arus $(\mathrm{cm} / \mathrm{s})$ & 26,31 & 2017) \\
\hline $\begin{array}{l}\text { Kedalaman } \\
(\mathrm{m})\end{array}$ & $\begin{array}{l}0,56- \\
1,13\end{array}$ & $0,2-4(\mathrm{BSN}, 2011)$ \\
\hline $\begin{array}{l}\text { Fosfat } \\
(\mathrm{mg} / \mathrm{L})\end{array}$ & 0,46 & $\begin{array}{l}\text { 0,02-1 (Pong-Masak dan } \\
\text { Sarira, 2015) }\end{array}$ \\
\hline $\begin{array}{l}\text { Nitrat } \\
(\mathrm{mg} / \mathrm{L})\end{array}$ & $<0,01$ & $\begin{array}{l}\text { 0,93-3,5 (Pong-Masak } \\
\text { dan Sarira, 2015) }\end{array}$ \\
\hline
\end{tabular}

\section{PEMBAHASAN}

\section{Pertumbuhan Mutlak}

Hasil penelitian menunjukan bahwa jarak tanam yang berbeda mempengaruhi pertumbuhan mutlak rumput laut Eucheuma cottonii. Hasil ini ditunjukan dengan analisis rata-rata pertumbuhan mutlak pada setiap perlakuan pada hasil uji ANOVA. Menurut Desy et al. (2016), jarak tanam pengikatan bibit pada tali ris merupakan salah satu faktor yang mempengaruhi pertumbuhan rumput laut.

Pertumbuhan mutlak paling tinggi terdapat pada perlakuan P1 jarak tanam 20 $\mathrm{cm}$ dengan nilai rata-rata $124 \mathrm{~g}$. Hal ini diduga pertumbuhan rumput laut akan 
semakin baik pertumbuhannya jika terdapat ruang untuk mengalirnya air yang membawa unsur hara serta berkurangnya persaingan antar talus dalam perebutan nutrien sehingga dapat meningkatkan proses difusi unsur hara pada rumput laut. Menurut Desy et al. (2016), unsur hara yang cukup ini diperoleh melalui arus landai yang terbentuk oleh angin di sekitar lingkungan sehingga menyebarkan unsur hara secara optimal dan meningkatkan proses difusi unsur hara pada rumput laut.

Intensitas cahaya merupakan faktor yang mempengaruhi pertumbuhan rumput laut. Cahaya matahari dibutuhkan oleh rumput laut dalam melakukan proses fotosintesis. Menurut Runtuboy dan Abadi (2018), pertumbuhan dan produksi rumput laut berhubungan erat dengan proses fotosintesis. Proses fotosintesis jauh lebih cepat terjadi pada intensitas cahaya yang tinggi daripada ketika tumbuh pada intensitas cahaya yang rendah. Rumput laut Eucheuma cottonii dapat membentuk fikoeritrin sebagai bentuk adaptasi pada kondisi perairan yang memiliki intensitas cahaya rendah. Menurut Cokrowati et al. (2020), Eucheuma cottonii membentuk pigmen lain yang disebut fikoeritrin sebagai bentuk adaptasi untuk antisipasi terhadap kebutuhan cahaya. Hal ini dapat diartikan bahwa cahaya matahari memiliki peranan penting dalam proses fotosintesis pada rumput laut.

Pada dasarnya semakin jauh jarak rumpun bibit rumput laut akan semakin banyak unsur hara yang dapat dimanfaatkan oleh rumput laut untuk tumbuh, tapi dengan keadaan alam yang memiliki ombak dan dan arus yang cukup kuat dapat menyebabkan talus rumput laut potong atau rontok. Jarak tanam yang tidak terlalu jauh dapat membantu untuk mengantisipasi kerontokan talus, hal ini diduga karena rumpun rumput laut akan saling bersentuhan seakan-akan berpegangan. Menurut Cokrowati et al. (2016), talus antar ikatan (antar rumpun) saling bersentuhan sehingga dapat memecah gerakan air. Hal itu dapat meminimalkan terjadinya kerontokan talus akibat patah oleh gerakan air.

\section{Laju Pertumbuhan Spesifik}

Hasil penelitian menunjukan bahwa jarak tanam yang berbeda mempengaruhi laju pertumbuhan spesifik rumput laut Eucheuma cottonii. Hasil ini dibuktikan dengan analisis rata-rata laju pertumbuhan spesifik pada setiap perlakuan. Menurut Pong-Masak dan Sarira (2018), jarak tanam antar rumpun bibit rumput laut dapat mempengaruhi kualitas dan kuantitas rumput laut.

Perlakuan yang memiliki nilai laju pertumbuhan tertinggi didapatkan pada perlakuan P1 jarak tanam $20 \mathrm{~cm}$ dengan nilai pertumbuhan $4,5 \% /$ hari. Pada setiap waktu penimbangan, rumput laut mengalami peningkatan pertumbuhan dan rumput laut mengalami laju pertumbuhan tertinggi pada minggu ke-4. Menurut Hilmi et al. (2013) dalam Cokrowati et al. (2016), rumput laut baik dipanen pada umur 30 hari (lebih awal). Hal ini karena rumput laut masih mengalami pertumbuhan yang bagus pada umur \pm 30 hari dan tidak mampu mempertahankan talusyang berat setelah melewati umur 30 hari.

Laju pertumbuhan spesifik rumput laut umumnya dipengaruhi oleh kompetisi dalam perebutan nutrien yang ada di perairan dikarenanakan jarak tanam yang terlalu rapat. Jarak tanam yang terlalu rapat juga dapat menyebabkan penumpukan kotoran atau lumpur-lumpur di bagian rumpun karena pergerakan air yang kurang optimal. Menurut Abdan dan Ruslaini (2013) dalam Cokrowati et al. (2016), dengan jarak yang rapat kemungkinan dapat terjadi penumpukan kotoran pada talus sehingga berakibat terganggunya proses fotosintesis.

\section{Rendemen Karaginan}

Rumput laut jenis Eucheuma cottonii merupakan salah satu rumput laut 
penghasil karaginan. Karaginan merupakan senyawa yang didapatkan melalui ekstrak rumput laut yang mengandung Kappa-karaginan. Karaginan merupakan senyawa yang terdiri dari beberapa unsur yang didapatkan melalui proses fotosintesis rumput laut. Menurut Fathmawati et al. (2014), karaginan merupakan senyawa hidrokoloid yang terdiri atas ester kalium, natrium, magnesium dan kalium sulfat dengan galaktosa 3,6 anhidrogalaktosa kopolimer.

Hasil uji ANOVA menunjukan bahwa jarak tanam tidak berpengaruh signifikan terhadap kandungan rendemen karaginan pada rumput lautEucheuma cottonii. Kandungan rendemen karaginan pada semua perlakuan berkisar antara $14 \%$ sampai $17 \%$.Hal ini diduga karena metode budidaya yang dilakukan pada rumput laut sama maka parameter yang diterima oleh rumput laut juga sama. Menurut Desy et al. (2016), penerapan metode budidaya yang sama, mengakibatkan kualitas lingkungan yang diterima rumput laut juga sama seperti cahaya matahari, salinitas, suhu dan nutrien di perairan.

Hasil rendemen karaginan yang didapatkan dalam penelitian ini tergolong rendah. Hal ini dapat dilihat pada penelitian Basiroh et al. (2016), dimana nilai rendemen karaginan pada hari ke-30 sebesar 31,48\%. Sedangkan dalam penelitian ini didapatkan nilai rendemen karaginan sebesar $14-17 \%$. Rendahnya nilai rendemen karaginan diduga dipengaruhi oleh kandungan nitrat yang ada di perairan. Nitrat merupakan salah satu nutrien yang penting dalam pertumbuhan rumput laut dan secara tidak langsung dapat mempengaruhi kadar karaginan.Menurut Budiyani et al. (2012), rumput laut yang kekurangan kadar nitrat akan menyebabkan terhambatnya pertumbuhan rumput laut. Pada penelitian ini didapatkan kadar nitrat di perairan sangat rendah yaitu $<0,01 \mathrm{mg} / \mathrm{L}$. Hal ini menunjukan bahwa nitrat yang tersedia diperairan tersebut kurang optimal. Kadar nitrat yang berlebih di perairan juga dapat bersifat racun bagi organisme air termasuk rumput laut. Menurut Pong-Masak dan Sarira (2015), secara umum kisaran nitrat untuk pertumbuhan optimum rumput laut yaitu $0,95-3,5 \mathrm{mg} / \mathrm{L}$.

\section{Kualitas Air}

Pengukuran parameter kualitas air merupakan hal yang penting dalam kegiatan budidaya rumput laut, tapi dalam hal ini parameter kualitas air bukan merupakan hal utama yang diamati. Salah satu parameter yang diamati adalah suhu. Suhu perairan merupakan faktor pembatas di perairan, bila suhu turun atau naik akan mempengaruhi kadar oksigen terlarut (DO) serta beberapa parameter lainnya akan ikut terpengaruhi secara tidak langsung. Menurut Fardiaz (1992) dalam Nur et al. (2016), kejenuhan oksigen dalam air dipengaruhi oleh suhu air, semakin tinggi suhu maka konsentrasi DO semakin turun.

Hasil pengukuran suhu yang dijumpai di lokasi penelitian berkisar antara 27-30 ${ }^{\circ} \mathrm{C}$. Hal ini sesuai dengan pernyataan Pong-Masak dan Sarira (2015), suhu yang optimum untuk melakukan budidaya rumput laut berkisar $26-30{ }^{\circ} \mathrm{C}$. Sedangkan nilai kandungan DO dalam perairan Pantai Siwak yaitu 4,64-5,7 ppm. Nilai ini menunjukan bahwa lokasi tersebut memiliki kadar DO yang baik untuk melakukan budidaya rumput laut. Menurut Nur et al. (2016), DO yang baik untuk melakukan budidaya rumput laut adalah 4,4-5,4 ppm. Rumput laut membutuhkan oksigen $\left(\mathrm{O}_{2}\right)$ ketika kondisi tidak ada intensitas cahaya yang cukup.

$$
\text { Hasil pengukuran derajat }
$$

keasaman atau $\mathrm{pH}$ yang dilakukan di perairan Pantai Siwak dijumpai hasil berkisar antara 7,9-9. Kisaran $\mathrm{pH}$ cukup jauh, hal ini diduga karena perbedan waktu pengamatan. Menurut Pong-Masak dan Sarira (2018), nilai $\mathrm{pH}$ yang baik untuk pertumbuhan rumput laut adalah 7,5-8,4. Sedangkan nilai salinitas yang dijumpai di perairan Pantai Siwak adalah 31-34 ppt. 
Salinitas di perairan tersebut sangat baik untuk pertumbuhan rumput laut, hal ini sesuai dengan pernyataan dari Pongarrang et al. (2013), salinitas yang baik untuk pertumbuhan rumput laut berkisar antara 28-35 ppt. Nilai salinitas di perairan Pantai Siwak tergolong tinggi, hal ini menunjukan bahwa daerah tersebut termasuk ke dalam daerah yang cukup panas.

Kedalaman di lokasi penelitian sangat dipengaruhi oleh pasang surut perairan. Tinggi perairan yang dijumpai di lokasi penelitian yaitu 0,56-1.,13 m. Kedalaman yang masih dapat ditoleransi adalah ketika cahaya matahari masih bisa menembus hingga ke rumput laut yang dibudidayakan. Menurut BSN (2011), kedalaman yang standar untuk melakukan budidaya rumput laut dengan patok dasar adalah 0,2-4 m. Untuk kecepatan arus dijumpai dengan kecepatan 20-26,31 $\mathrm{cm} / \mathrm{s}$. Kecepatan arus memiliki peranan penting dalam membawa nutrisi yang dibutuhkan oleh rumput laut untuk tumbuh. Menurut Togatorop et al. (2017), kecepatan yang optimal untuk budidaya rumput laut adalah $20-40 \mathrm{~cm} / \mathrm{s}$.

Fosfat dan nitrat adalah nutrien penentu kesuburan di suatu perairan. Kadar fosfat yang didapatkan pada sampel air Pantai Siwak adalah 0,46 mg/L, sedangkan kadar nitrat tergolong rendah yaitu $<0,01 \mathrm{mg} / \mathrm{L}$. dengan kandungan nitrat yang rendah ini menyebabkan rumput laut kurang optimal dalam tumbuh, tapi rumput laut Eucheuma cottonii dapat tumbuh. Menurut Pong-Masak dan Sarira (2015), kadar fosfat 0,02-1 mg/L dan kadar nitrat $0,9-3,5 \mathrm{mg} / \mathrm{L}$.

\section{KESIMPULAN}

Adapun kesimpulan yang dapat diambil dari penelitian ini adalah jarak tanam memiiki pengaruh yang nyata terhadap pertumbuhan rumput laut Eucheuma cottonii kultur jaringan dengan metode patok dasar (off bottom). Dengan jarak tanam terbaik dalam penelitian ini adalah P1 $(20 \mathrm{~cm})$.

\section{DAFTAR PUSTAKA}

Asikin, A. N., I. Kusumaningrum, dan D. Sutono. 2015. Ekstraksi dan Karakterisasi SifatFungsional Karaginan Kappaphycus alvarezii Asal Pesisis Kabupaten Kutai Timur.Jurnal Ilmu dan Teknologi Kelautan Tropis. Vol. 7(1) : 49-58.

Basiroh, S., M. Ali, B. Putri. 2016. Pengaruh Priode Panen Yang Berbeda Terhadap KualitasKaraginan Rumput Laut Kappaphycus alvarezii Kajian Rendemen dan OrganoleptikKaraginan. Maspari Journal. Vol. 8(2) : 127-135.

Budiyani, F. B., K. Suwartimah, Sunaryo. 2012. Pengaruh Penambahan Nitrogen dengan Konsentrasi yang Berbeda terhadap Laju Pertumbuhan Rumput Laut Caulerpa recemosa var. ufivera. Journal of Marine Research. Vol. 1(1) : 10-18.

BSN (Badan Standar Nasional). 2011. Produksi Bibit Rumput Laut Kotoni (Eucheuma cottonii) - Bagian 1: Metode Lepas Dasar. Jakarta.

Cokrowati, N., A. R. Spitri, dan Rusman. 2016. Pertumbuhan Rumput Laut Kappaphycus alvarezii Hasil Kultur Jaringan Pada Jarak Tanam Yang Berbeda. Depik. Vol. 5(1) : 12-18.

Cokrowati, N., A. Arjuni, dan Rusman. 2018. Pertumbuhan Rumput Laut Kappaphycus alvarezii Hasil Kultur Jaringan. Jurnal Biologi Tropis. Vol. 18(2) : 216-223.

Cokrowati, N., S. L. Yuniarti, N. Daniarti, M. Supiandi, Bangun. 2020. Kandungan Klorofil- $a$ dan Fikoeritrin Kappaphycus alvarezii Hasil Kultur Jaringan dan dibudidayakan pada Jarak Tanam Berbeda. Jurnal Biologi Tropis. Vol. 20(1) : 125-131. 
Desy, A. S,. M. Izzati, E. Prihastanti. 2016. Pengaruh Jarak Tanam Pada Metode Longline Terhadap Pertumbuhan Dan Rendemen Agar Gracilaria verrucosa (Hudson) Papenfuss. Jurnal Biologi. Vol. 5(2) : 11-22.

Failu, I., E. Supriyono, S. H. Suseno. 2016. Peningkatan Kualitas Karagenan Rumput Laut Kappaphycus alvarezii dengan Metode Budidaya Keranjang Jaring. Jurnal Akuakultur Indonesia. Vol. 15(2) : 124-131.

Fathmawati, D., M. R. P. Abidin, A. Roesyadi. 2014. Studi Kinetika Pembentukan Karaginan dari Rumput Laut. Jurnal Teknik Pomits. Vol. 3(1) : 27-32.

Nur, A.I., H. Syam, dan Patang. 2016. Pengaruh Kualitas Air Terhadap ProduksiRumput Laut (Kappaphycus alvarezii). Jurnal Pendidikan TeknologiPertanian. Vol. 2(1).

Pongarrang, D., A. Rahman dan W. Iba. 2013. Pengaruh Jarak Tanam Dan Bobot Bibit Terhadap Pertumbuhan Rumput Laut Kappaphycus alvarezii Menggunakan Metode Vertikultur. Jurnal Mina Laut Indonesia. Vol. 3(12) : 94-112.
Pong-Masak, P. R., N. H. Sarira. 2015. Petunjuk Teknis Teknologi Budidaya Rumput Laut Eucheuma cotoonii dengan Metode Vertikultur. Gorontalo: Loka Riset Budidaya Rumput Laut.

2018. Penentuan Jarak Tanam Optimal Antar Rumpun Bibit pada Metode Vertikultur Rumput Laut. Jurnal Perikanan Universitas Gadjah Mada. Vol. 20(1) : 23-30.

Runtuboy, N., S. Abadi. 2018. Pengaruh Kedalaman Terhadap Perkembangan Rumput Laut Kotoni Hasil Kultur Jaringan. Jurnal Penyuluhan Perikanan dan Kelautan. Vol. 12(3) : 196-206.

Togatorop, A. P., I. G. N. P. Dirgayusa, N. L. P. R. Puspitha. 2017. Studi Pertumbuhan Rumput Laut Jenis Kotoni (Eucheuma cottonii) dengan Menggunakan Metode Kurung Dasar dan Lepas Dasar di Perairan Geger, Bali. Journal of Marine and Aquatic Sciences. Vol.3(1) : 47-58.

Wijayanto, T., M. Hendri, dan R. Aryawati. 2011. Studi Pertumbuhan RumputLaut Eucheuma cottonii dengan Berbagai Metode Penanaman yang berbeda di Perairan Kalianda, Lampung Selatan. Maspari Journal. Vol. 1(3) : 51-57. 